\title{
Hubungan Karakteristik dan Kebiasaan Menyikat Gigi dengan Kejadian Abrasi Gigi pada Pegawai Yayasan Masjid Al-Ikhlas Cilandak Jakarta
}

\section{The Relationship Between Characteristics and Habits of Brushing Teeth with the Incidence of Dental Abrasion in Employees of The Al-Ikhlas Masjid Cilandak Foundation in Jakarta}

\author{
Ngatemi $^{(1)}$, Erna Sariana ${ }^{(2)}$, Khalida Hilwa $^{(1)}$ \\ ${ }^{(1)}$ Poltekkes Kemenkes Jakarta I \\ ${ }^{(2)}$ Poltekkes Kemenkes Jakarta III \\ Korespondensi Penulis: Ngatemi, Poltekkes Kemenkes Jakarta I \\ Email: ngatemipoltekkes@gmail.com
}

\begin{abstract}
ABSTRAK
Abrasi disebabkan oleh penyikatan gigi ke arah horizontal dan dengan penekanan berlebihan. Penelitian ini bertujuan untuk mendapatkan gambaran hubungan karakteristik pegawai dan kebiasaan menyikat gigi dengan kejadian abrasi gigi pada pegawai Yayasan Masjid Al-Ikhlas Cilandak Jakarta. Penelitian ini merupakan penelitian deskriptif dengan desain cross sectional. Sampel penelitian menggunakan metode total sampling berjumlah 32 orang pegawai Yayasan Masjid Al-Ikhlas. Pengumpulan data melalui wawancara langsung dan observasi dengan mengisi lembar checklist dan kartu status kelainan gigi (abrasi gigi). Analisis data dilakukan secara univariat dan bivariat. Hasil analisis univariat menunjukkan kejadian abrasi gigi sebagian besar dalam kategori tinggi $(53,1 \%)$, umur pegawai $\geq 38$ tahun $(56,3 \%)$, jenis kelamin perempuan $(56,3 \%)$, frekuensi menyikat gigi $<3 \mathrm{kali}(62,5 \%)$, dan teknik menyikat gigi sebagian besar baik (56,3\%). Hasil analisis bivariat, variabel yang berhubungan secara bermakna dengan kejadian abrasi gigi adalah frekuensi menyikat gigi ( $\mathrm{p}$ value $=0,035$ dan OR $=7,000 ; 95 \% \mathrm{CI}$ $=1,386-35,345)$, dan teknik menyikat gigi ( $\mathrm{p}$ value $=0,029$ dan $\mathrm{OR}=7,333 ; 95 \% \mathrm{CI}=1,467-36,664)$.
\end{abstract}

Kata Kunci : Abrasi Gigi, Karakteristik, dan Kebiasaan Menyikat Gigi.

\begin{abstract}
Abrasion caused by brushing teeth in a horizontal direction and with excessive emphasis. This study aims to obtain an overview of the relationship between the characteristics and habits of brushing teeth with the incidence of dental abrasion in employees of the Al-Ikhlas Masjid Cilandak Foundation in Jakarta. This research is a descriptive study with a cross sectional design. The research sample used total sampling totaling 32 employees of Masjid Al-Ikhlas Foundation. Data collection through direct interviews and observations by filling out checklist sheets and dental abnormalities (tooth abrasion) cards. Data analysis was conducted in univariate and bivariate. The results of univariate analysis showed that the incidence of tooth abrasion was mostly in the high category (53.1\%), employee age > 38 years (56.3\%), female sex (56.3\%), tooth brushing frequency <3 times (62, 5\%), and the tooth brushing technique is mostly good (56.3\%). The results of bivariate analysis, variables that were significantly associated with dental abrasion events were the frequency of tooth brushing ( $\mathrm{p}$ value $=0,035$ and $O R=7,000 ; 95 \% C I=1,386-35,345)$, and tooth brushing techniques (p value $=0,029$ and OR =7,333; 95\% CI $=1,467-36,664)$.
\end{abstract}

Keywords: Dental Abrasion, Characteristics, and Habit of Brushing Teeth. 


\section{PENDAHULUAN}

Masalah gigi dan mulut di Indonesia sampai saat ini masih menjadi salah satu masalah kesehatan yang membutuhkan penanganan. Hasil Riset Kesehatan Dasar (RISKESDAS) tahun 2013 menyatakan prevalensi nasional masalah gigi dan mulut adalah 25,9\% dan proporsi penduduk yang memiliki kebiasaan menyikat gigi setiap hari adalah sebesar $94,2 \%$ sebanyak 15 provinsi berada dibawah prevalensi nasional. Perilaku benar dalam menyikat gigi berkaitan dengan faktor gender, ekonomi, dan daerah tempat tinggal. Penduduk Indonesia sebagian besar menyikat gigi pada saat mandi pagi maupun mandi sore $(76,6 \%)$. di Indonesia, hanya $2,3 \%$ penduduk yang menyikat gigi dengan benar, yaitu setelah makan pagi dan sebelum tidur. Provinsi tertinggi untuk perilaku menyikat gigi dengan benar adalah Sulawesi Barat yaitu 8,0 persen (Riskesdas, 2013).

Kondisi tersebut menggambarkan cukup rawannya kesehatan gigi dan mulut masyarakat di Indonesia. Salah satu bentuk masalah kesehatan gigi pada seseorang adalah timbulnya abrasi gigi. Terjadinya kerusakan pada jaringan gigi akibat benda asing, seperti sikat gigi dan pasta gigi adalah bentuk dari abrasi gigi. Abrasi gigi akan mengakibatkan terbentuknya irisan atau parit berbentuk ' $\mathrm{V}$ ' pada akar diantara mahkota dan gingiva. Kondisi tersebut membuat gigi menjadi sensitif ketika menerima rangsangan termis baik panas maupun dingin. Abrasi dalam bentuk lanjut berisiko fraktur (patah) pada daerah servikal gigi. Abrasi dapat terjadi pada setiap gigi, tapi biasanya lebih banyak terjadi pada servikal bagian bukal gigi insisivus, kaninus, dan premolar di kedua rahang. Abrasi gigi terjadi sejak menggunakan sikat gigi setelah gigi permanen tumbuh dan baru terlihat akibatnya ketika dewasa (Kalangie, 2016).

Salah satu upaya pemeliharaan kesehatan gigi dan mulut yang dapat dilakukan oleh masyarakat untuk mencegah abrasi adalah menyikat gigi. Tujuan menyikat gigi adalah untuk menghilangkan sisa makanan, timbunan mikroorganisme dan plak supra gingival yang baru terbentuk dan belum terklasifikasi. Keberhasilan pemeliharaan kebersihan gigi lewat tindakan menyikat gigi dipengaruhi oleh teknik atau cara menyikat gigi yang tepat (Khotimah, 2017).

Penelitian sebelumnya di Kota Manado mendapatkan $74,15 \%$ responden mengalami abrasi gigi (Kalangie, 2016). Di wilayah DKI Jakarta, didapatkan prevalensi penduduk yang mempunyai masalah gigi dan mulut dalam 12 bulan terakhir (potential demand) pada tahun 2013 sebesar 29,1\% lebih tinggi dibandingkan angka nasional sebesar 25,9\%. Proporsi penduduk yang memiliki kebiasaan menyikat gigi setiap hari adalah sebesar $98,1 \%$. Meskipun demikian, proporsi penduduk menyikat gigi dengan benar hanya sebesar $3,5 \%$. Kondisi tersebut menggambarkan bahwa DKI Jakarta sebagai Ibukota negara juga cenderung masih memiliki masalah terkait dengan gigi dan mulut (Riskesdas, 2013).

Tujuan dari penelitian ini adalah untuk mengetahui hubungan karakteristik pegawai dan kebiasaan menyikat gigi dengan kejadian abrasi gigi pada pegawai Yayasan Masjid AlIkhlas Cilandak Jakarta tahun 2018.

\section{SUBYEK DAN METODE}

Penelitian ini merupakan penelitian analitik dengan desain cross sectional (potong lintang). Penelitian ini dilaksanakan di Yayasan Masjid Al-Ikhlas Cilandak Jakarta. Waktu penelitian pada bulan April-Mei 2018. Populasi pada penelitian ini adalah seluruh pegawai Yayasan Masjid Al-Ikhlas Cilandak Jakarta yang berjumlah 35 orang. Teknik dalam pengambilan sampel ini yaitu total sampling, dimana semua anggota populasi digunakan sebagai sampel. Kriteria inklusi pada penelitian ini adalah seluruh pegawai tetap maupun honorer yang hadir pada saat pengambilan data primer serta bersedia menjadi responden.

Data yang digunakan dalam penelitian adalah data primer, melalui wawancara langsung dan observasi dengan mengisi lembar checklist dan mengisi kartu status kelainan gigi yaitu abrasi gigi. Analisis Data dilakukan secara univariat (distribusi frekuensi) dan bivariat (uji Kai Kuadrat).

\section{HASIL}

1. Gambaran Kejadian Abrasi Gigi

Kejadian abrasi gigi diukur
berdasarkan banyaknya gigi yang
mengalami abrasi dari hasil pemeriksaan.
Dalam penelitian ini, pengkategorian abrasi
gigi dilakukan berdasarkan nilai tengah
(mean/median), karena belum ada standar
baku penentuan nilai tinggi rendahnya
abrasi gigi. Penentuan nilai tengah
dilakukan menurut uji kenormalan data
dengan menggunakan nilai skewness yang


dibagi dengan nilai standar error-nya. Pada variabel kejadian abrasi gigi, diperoleh nilai skewness yang dibagi dengan nilai standar error-nya adalah 0,997, sehingga pengkategorian variabel ini berdasarkan nilai mean yaitu 6,69 dibulatkan 7 . Kategorinya adalah tinggi jika jumlah abrasi gigi $>7$ buah gigi, dan rendah jika jumlah abrasi gigi $\leq 7$ buah gigi. Secara jelas, hasil jawaban responden dapat dilihat dalam tabel 1.

2. Gambaran Umur, Jenis Kelamin, Frekuensi Menyikat Gigi, dan Teknik Menyikat Gigi

Dalam penelitian ini, kategori umur responden dilakukan berdasarkan nilai tengah (mean/median), karena belum ada standar baku penentuan umur untuk kesehatan gigi. Penentuan nilai tengah umur dilakukan menurut uji kenormalan data dengan menggunakan nilai skewness yang dibagi dengan nilai standar error-nya, yaitu 1,01, sehingga pengkategorian umur berdasarkan nilai mean (38 tahun). Kategorinya adalah umur $>38$ tahun, dan $\leq$ 38 tahun. Untuk lebih jelasnya dapat dilihat dalam tabel 2.

3. Hasil Analisis Bivariat Umur, Jenis Kelamin, Frekuensi Menyikat Gigi, dan Teknik Menyikat Gigi dengan Kejadian Abrasi Gigi

Hasil analisis bivariat antara umur, jenis kelamin, frekuensi menyikat gigi, dan teknik menyikat gigi dengan kejadian abrasi gigi pada pegawai menggunakan uji Kai Kuadrat, dapat dilihat pada tabel 3.

Tabel 1. Distribusi Frekuensi Kejadian Abrasi Gigi pada Pegawai di Yayasan Masjid Al-Ikhlas Cilandak Jakarta

Tahun 2018

\begin{tabular}{|c|c|c|}
\hline Kejadian Abrasi Gigi & Frekuensi (n) & Persentase (\%) \\
\hline Tinggi & 17 & 53,1 \\
\hline Rendah & 15 & 46,9 \\
\hline Total & 32 & 100,0 \\
\hline
\end{tabular}

Tabel 2. Distribusi Frekuensi Umur, Jenis Kelamin, Frekuensi Menyikat Gigi, dan Teknik Menyikat Gigi pada Pegawai di Yayasan Masjid Al-Ikhlas Cilandak Jakarta Tahun 2018

\begin{tabular}{|c|c|c|c|}
\hline Variabel & Kategori & Frekuensi (n) & Persentase (\%) \\
\hline \multirow[b]{2}{*}{ Umur } & $>38$ tahun & 14 & 43,8 \\
\hline & $\leq 38$ tahun & 18 & 56,2 \\
\hline \multirow{2}{*}{ Jenis kelamin } & Laki-laki & 14 & 43,8 \\
\hline & Perempuan & 18 & 56,2 \\
\hline \multirow{2}{*}{ Frekuensi Menyikat Gigi } & < 3 kali & 20 & 62,5 \\
\hline & $\geq 3$ kali & 12 & 37,5 \\
\hline \multirow{2}{*}{ Teknik Menyikat Gigi } & Kurang & 14 & 43,8 \\
\hline & Baik & 18 & 56,2 \\
\hline Total & & 32 & 100,0 \\
\hline
\end{tabular}


Tabel 3. Hasil Analisis Bivariat Hubungan Umur, Jenis Kelamin, Frekuensi Menyikat Gigi, dan Teknik Menyikat Gigi Dengan Kejadian Abrasi Gigi pada Pegawai di Yayasan Masjid Al-Ikhlas Cilandak Jakarta Tahun 2018

\begin{tabular}{|c|c|c|c|}
\hline Variabel & p value & $\begin{array}{c}\text { OR } \\
(95 \% \mathrm{CI})\end{array}$ & Kesimpulan \\
\hline $\begin{array}{l}\text { Hubungan Umur Dengan kejadian } \\
\text { abrasi gigi pada pegawai }\end{array}$ & 0,166 & $\begin{array}{c}3,666 \\
(0,829-15,628)\end{array}$ & $\begin{array}{l}\text { Tidak ada hubungan } \\
\text { bermakna }\end{array}$ \\
\hline $\begin{array}{l}\text { Hubungan jenis kelamin dengan } \\
\text { kejadian abrasi gigi pada pegawai }\end{array}$ & 0,448 & $\begin{array}{c}2,250 \\
(0,536-9,450)\end{array}$ & $\begin{array}{c}\text { Tidak ada hubungan } \\
\text { bermakna }\end{array}$ \\
\hline $\begin{array}{l}\text { Hubungan frekuensi menyikat gigi } \\
\text { dengan kejadian abrasi gigi pada } \\
\text { pegawai }\end{array}$ & 0,035 & $\begin{array}{c}7,000 \\
(1,386-35,345)\end{array}$ & $\begin{array}{l}\text { Ada hubungan } \\
\text { bermakna }\end{array}$ \\
\hline $\begin{array}{l}\text { Hubungan teknik menyikat gigi } \\
\text { dengan kejadian abrasi gigi pada } \\
\text { pegawai }\end{array}$ & 0,029 & $\begin{array}{c}7,333 \\
(1,467-36,664)\end{array}$ & $\begin{array}{l}\text { Ada hubungan } \\
\text { bermakna }\end{array}$ \\
\hline
\end{tabular}

Berdasarkan tabel 1, diketahui pegawai yang mengalami abrasi gigi kategori tinggi, yaitu sebanyak 17 orang $(53,1 \%)$, sedangkan pegawai yang abrasi giginya kategori rendah, yaitu sebanyak 15 orang $(46,9 \%)$.

Adapun pada tabel 2, diketahui sebagian besar pegawai berumur $\leq 38$ tahun, yaitu sebanyak 18 orang $(56,3 \%)$, jenis kelamin pegawai perempuan yaitu sebanyak 18 orang (56,3\%), frekuensi menyikat gigi < 3 kali sebanyak 20 orang $(62,5 \%)$, dan teknik menyikat gigi dalam kategori baik yaitu sebanyak 18 orang $(56,3 \%)$.

Selanjutnya, pada tabel 3 diketahui variabel yang memiliki hubungan bermakna dengan kejadian abrasi gigi adalah frekuensi menyikat gigi ( $\mathrm{p}$ value $=0,035$ dan $\mathrm{OR}=7,000$ ; 95\% CI 1,386 - 35,345) dan teknik menyikat gigi ( $\mathrm{p}$ value $=0,029$ dan $\mathrm{OR}=7,333 ; 95 \% \mathrm{CI}$ $=1,467-36,664)$. Sedangkan yang tidak berhubungan secara bermakna dengan kejadian abrasi gigi adalah variabel umur ( $\mathrm{p}$ value $=$ 0,166 ) dan jenis kelamin ( $\mathrm{p}$ value $=0,448$ )

\section{DISKUSI}

1. Kejadian Abrasi Gigi

Kejadian abrasi gigi diukur berdasarkan banyaknya gigi yang mengalami abrasi dari hasil pemeriksaan. Dari hasil penelitian, diketahui pegawai yang mengalami abrasi gigi kategori tinggi, yaitu sebanyak 17 orang $(53,1 \%)$, sedangkan pegawai yang abrasi giginya kategori rendah, yaitu sebanyak 15 orang $(46,9 \%)$.
Abrasi gigi merupakan hilangnya struktur gigi akibat dari keausan mekanis yang abnormal yang secara klinis dapat dilihat membentuk irisan atau parit berbentuk ' $\mathrm{V}$ ' pada daerah cervical gigi. Abrasi dapat terjadi pada setiap gigi, tapi biasanya lebih banyak terjadi pada servikal bagian bukal gigi insisivus, kaninus, dan premolar di kedua rahang. Abrasi gigi terjadi sejak menggunakan sikat gigi setelah gigi permanen tumbuh dan baru terlihat akibatnya ketika dewasa. (Kalangie, 2016).

Penelitian Kalangie (2016) di lingkungan II Kelurahan Maasing, Kecamatan Tuminting, Kota Manado juga menjelaskan bahwa sebesar 74,15\% masyarakat mengalami abrasi gigi. Namun dalam penelitian tersebut tidak menjelaskan tentang frekuensi gigi yang mengalami abrasi pada masing-masing responden.

Dalam penelitian ini, sebagian besar pegawai mengalami abrasi gigi kategori tinggi, yaitu lebih dari 7 buah gigi. Kondisi tersebut menggambarkan cukup tingginya masalah kesehatan gigi dan mulut pada pegawai di Yayasan Masjid Al Ikhlas Cilandak. Oleh sebab itu, diperlukan berbagai upaya untuk menurunkan persentase abrasi gigi, misalnya dengan memberikan penyuluhan tentang cara menjaga kesehatan gigi dan mulut, teknik menyikat gigi, dan sebagainya. 
2. Umur

Berdasarkan hasil penelitian, diketahui sebagian besar pegawai berumur $\leq 38$ tahun, yaitu sebanyak 18 orang $(56,3 \%)$. Hasil analisis bivariat membuktikan tidak adanya hubungan bermakna antara umur dengan kejadian abrasi gigi pada pegawai ( $\mathrm{p}$ value $=0,166$ )

Meskipun tidak terdapat hubungan bermakna antara umur dengan kejadian abrasi gigi, namun proporsi abrasi gigi kategori tinggi lebih banyak ditemukan pada pegawai yang berumur $\geq 38$ tahun $(66,7 \%)$ dibandingkan pegawai yang berumur $<38$ tahun $(35,7 \%)$.

Hasil penelitian ini sesuai dengan penelitian yang dilakukan oleh Kalangie, dkk (2016) di lingkungan II Kelurahan Maasing, Kecamatan Tuminting, Kota Manado yang menyatakan bahwa dari hasil distribusi subjek penelitian penderita abrasi gigi berdasarkan usia menunjukkan adanya pola peningkatan abrasi gigi yang terjadi seiring dengan meningkatnya usia. Meskipun dalam penelitian tersebut, kategori umur tidak dikelompokkan berdasarkan nilai rata-rata, namun berdasarkan interval umur 10 tahun. Hasil penelitiannya menunjukkan bahwa kelompok usia tertinggi 56-65 tahun merupakan kelompok usia terbanyak mengalami abrasi gigi yaitu seluruh subjek penelitian (100\%), dan kelompok usia yang memiliki abrasi paling sedikit ditemukan pada kelompok usia terendah 16-25 tahun (50\%).

Hal tersebut cukup membuktikan bahwa semakin tua umur seseorang, maka semakin besar risiko untuk mengalami abrasi gigi. Dalam penelitian ini, didukung oleh nilai OR sebesar 3,666 $(95 \% \mathrm{CI}=$ 0,829-15,628), artinya OR > 1 sehingga dapat dijelaskan bahwa umur sebagai faktor risiko timbulnya abrasi gigi sebesar 3,666 kali.

3. Jenis Kelamin

Berdasarkan hasil penelitian, diketahui sebagian besar jenis kelamin pegawai adalah perempuan yaitu sebanyak 18 orang $(56,3 \%)$. Hasil analisis bivariat membuktikan tidak adanya hubungan bermakna antara jenis kelamin dengan kejadian abrasi gigi pada pegawai ( $\mathrm{p}$ value $=0,448$ ).
Hasil penelitian ini sejalan dengan penelitian yang dilakukan oleh Kalangie, dkk (2016) di lingkungan II Kelurahan Maasing, Kecamatan Tuminting, Kota Manado yang mengemukakan bahwa kejadian abrasi gigi memiliki peluang yang hampir sama antara laki-laki dan perempuan. Distribusi abrasi gigi berdasarkan jenis kelamin menunjukkan bahwa sebagian besar subjek penelitian baik yang berjenis kelamin laki-laki $(77,4 \%)$ maupun berjenis kelamin perempuan (73\%) mengalami abrasi gigi.

4. Frekuensi Menyikat Gigi

Berdasarkan hasil penelitian, diketahui sebagian besar frekuensi menyikat gigi pegawai adalah $<3$ kali sebanyak 20 orang $(62,5 \%)$. Hasil analisis bivariat membuktikan adanya hubungan bermakna antara frekuensi menyikat gigi dengan kejadian abrasi gigi pada pegawai ( $\mathrm{p}$ value $=0,035$ dan $\mathrm{OR}=7,000 ; 95 \% \mathrm{CI}$ $=1,386-35,345$ ).

Menyikat gigi adalah cara yang dikenal masyarakat untuk menjaga kebersihan gigi dan mulut. Menyikat gigi merupakan tindakan preventif dalam menuju keberhasilan dan kesehatan rongga mulut yang optimal. Tujuan menyikat gigi adalah untuk menghilangkan sisa makanan, timbunan mikroorganisme dan plak supragingival yang baru terbentuk dan belum terklasifikasi (Kalangie, dkk, 2016)).

Mengenai frekuensi penyikatan gigi telah disetujui bahwa gigi sebaiknya dibersihkan 3 kali sehari, setiap kali sesudah makan dan sebelum tidur. Tetapi di dalam prakteknya tidak selalu dapat dilakukan, terutama pada siang hari dimana seseorang berada di kantor, sekolah atau ditempat lainnya. Manson, 1971 berpendapat bahwa penyikatan gigi sebaiknya minimal dua kali sehari, yaitu setelah makan pagi dan sebelum tidur.

Penelitian Dewi (2019) terhadap Mahasiswa Asrama Galuh Ciamis Jawa Barat di Yogyakarta, mengemukakan bahwa responden yang mempunyai perilaku menyikat gigi sedang mengalami abrasi gigi ringan $(51.4 \%)$. Hal tersebut menggambarkan bahwa semakin besar frekuensi menyikat gigi, akan semakin tinggi risiko terjadinya abrasi gigi, apalagi 
didukung oleh teknik menyikat gigi yang kurang baik.

5. Teknik Menyikat Gigi

Berdasarkan hasil penelitian, diketahui sebagian besar teknik menyikat gigi pegawai dalam kategori baik yaitu sebanyak 18 orang (56,3\%). Hasil analisis bivariat membuktikan adanya hubungan bermakna antara teknik menyikat gigi dengan kejadian abrasi gigi pada pegawai ( $\mathrm{p}$ value $=0,029$ dan $\mathrm{OR}=7,333 ; 95 \% \mathrm{CI}$ $=1,467-36,664$ ).

Teknik menyikat gigi adalah cara yang umum dianjurkan untuk membersihkan deposit lunak pada permukaan gigi dan gusi, disamping itu, merupakan tindakan preventif dalam menuju keberhasilan dan kesehatan rongga mulut yang optimal. Oleh karena itu, teknik menyikat gigi harus dimengerti dan dilaksanakan secara aktif dan teratur. Terdapat teknik-teknik yang berbeda-beda untuk membersihkan gigi dan memijat gusi dengan sikat gigi.

Berdasarkan hasil penelitian yang dilakukan Natamiharja dan Hayana di Riau pada tahun 2009, dimana dari 200 orang responden 100 orang $(50 \%)$ gigi menggunakan metode horizontal, 54 orang (54\%) diantaranya mengalami abrasi gigi. Metode horizontal merupakan metode yang paling banyak digunakan karena penggunaannya yang sederhana dan mudah. Abrasi dapat terjadi dikarenakan dalam penggunaan metode horizontal gigi secara terus menerus mendapat gesekan yang sejajar pada permukaan enamelnya, apalagi jika setiap hari dilakukan dengan tekanan yang berlebihan.

Sitanaya (2017) yang melakukan penelitian terhadap siswa kelas XII SMA Negeri 1 Galesong Selatan Kabupaten Takalar juga membuktikan bahwa ada pengaruh antara teknik menyikat gigi terhadap terjadinya abrasi di servikal gigi ( $\mathrm{p}$ value $=0,005$ dan nilai $\mathrm{r}=0,442$ ). Menyikat gigi dengan metode horizontal, lebih besar pengaruhnya menyebabkan abrasi dibandingkan dengan metode vertikal. Responden yang menggunakan teknik menyikat gigi secara horizontal lebih banyak mengalami abrasi gigi dengan jumlah 17 responden berbeda dengan responden yang menggunakan teknik menyikat gigi secara vertikal yang hanya berjumlah 6 responden.

Dalam penelitian ini juga membuktikan bahwa teknik menyikat gigi yang kurang baik yaitu secara horizotal, akan meningkatkan risiko sebesar 7 kali menyebabkan abrasi gigi dibandingkan dengan responden yang menyikat gigi secara baik yaitu metode vertikal.

\section{KESIMPULAN}

Dari hasil penelitian, diketahui pegawai yang mengalami abrasi gigi kategori tinggi, yaitu sebanyak $53,1 \%$, sebagian besar pegawai berumur $\leq 38$ tahun $(56,3 \%)$, jenis kelamin perempuan $(56,3 \%)$, frekuensi menyikat gigi < 3 kali (62,5\%), dan teknik menyikat gigi pegawai dalam kategori baik $(56,3 \%)$. Variabel yang membuktikan adanya hubungan bermakna dengan kejadian abrasi gigi adalah frekuensi menyikat gigi ( $\mathrm{p}$ value $=0,035$ dan $\mathrm{OR}=7,000 ; 95 \% \mathrm{CI}=1,386-35,345)$ dan teknik menyikat gigi ( $\mathrm{p}$ value $=0,029$ dan OR $=7,333 ; 95 \% \mathrm{CI}=1,467-36,664)$.

\section{DAFTAR PUSTAKA}

Dewi, NM. (2019). Gambaran Perilaku Menyikat Gigi dan Abrasi Gigi Pada Mahasiswa Asrama Galuh Ciamis Jawa Barat di Yogyakarta. Karya Tulis Ilmiah Jurusan Keperawatan Gigi Poltekkes Kemenkes Yogyakarta.

Kalangie, P. B. (2016). "Gambaran Abrasi Gigi Ditinjau Dari Metode Menyikat Gigi Pada Masyarakat Di Lingkungan II Kelurahan Maasing Kecamatan Tuminting Kota Manado. Jurnal Ilmiah Farmasi - UNSRAT Vol. 5 No. 2 Mei 2016.

Khotimah, K. (2017). “Gambaran Penatalaksanaan Kasus Gigi 44, 45 Abrasi Servikal Pada Pasien NN. F Di Klinik Jurusan Keperawatan Gigi Bandung."

Natamiharja L, Hayana NB. (2009). Abrasi gigi berdasarkan umur, pendidikan, perilaku menyikat gigi. Dentika Dental Journal.

Riskesdas, (2013). "Riset Kesehatan Dasar (RISKESDAS) 2013," Laporan Nasional 2013, pp. 1-384. doi: 1 Desember 2013.

Sitanaya, RI. 2017. Pengaruh Teknik Menyikat Gigi Terhadap Terjadinya Abrasi Pada Servikal Gigi. Media Kesehatan Gigi Vol. 16 No. 1 Tahun 2017. 